\title{
The influence of price and label on the consumption of persuasive packaging: considerations for the development of products
}

\author{
Solon Bevilacqua, Pedro Capingote \\ Faculdade de Ciências e Tecnologia, Universidade Federal de Goiás - UFG \\ e-mails: solbev@gmail.com
}

\begin{abstract}
Labels acts as a silent seller, showing product characteristics and benefits. In the area of product development, this practice could suggest persuasion and seduction through abusing practices as Greenwashing, Trade Dress, and questionable quality certifications. In this context, this paper has the objective of researching price and label information influence in persuasive packaging consumption. Two paired experiments analyze price and information influences, manipulating these variables (price and label information) to verify behavior on 60 frequent consumers. Promotional price tags and new labels were created in order to verify consumer choices. Contrary to expectations, despite of warnings about suspicious strategies used in packaging, consumers kept buying small amounts and products of lower quality or unethical, because of their lower prices. We conclude that increasing each product's information on the label, will not inhibit persuasive product consumption, otherwise will improve the final decision, just like it will improve the choosing process of products' baskets. Theoretical contribution: the consumer should be seen as an individual of groupings of products and not of isolated items. Excession is made for the case of Greenwhasing which has presented itself as an effective practice of market seduction. Consumer units or Diderot units have been investigated as a consumer effect for a specific consumer choice over subsequent goods. Practical contribution: from applied studies aimed at the search for consumer well-being and quality of life, we seek in this study to highlight healthy marketing practices that have less adverse effects on consumption and after sales of goods. Studies on Transformative Consumer Research.
\end{abstract}

Keywords: consumer, label, packaging, price, brand.

\section{Introduction}

Retailing practices are now a passive sales strategy that puts together label and pricing, establishing the "silent seller", according to Dichter (1957). When these elements are oriented to intensify competitive environments, they are persuasive (PILDITCH, 1961) because of the inclusion of three strategic aspects of packaging: communication, functionality and environmental awareness (HANSEN, 1986). Therefore, we are facing what Lewis (1991) called brand central values personification. Discussion here is related to the use of packaging as the silent seller that seduces and persuades consumers, setting the objective of this paper, which is to identify the influence of price and label in persuasive packaging consumption.

A context of seduction is created by an efficient communication strategy tied to a competitive price. The idea is that the consumer compares competition options and makes the decision of buying the product with seducing characteristics and good price. A bottle label may suggest containing more product than what it actually has; expressions like grapes nectar may suggest something better than a juice; and a game with big and small letters may hide some nutritional facts. When a firm mixes pricing and seduction strategies for packaging, it will be able to disseminate its behavior or show a responsible attitude which is not exactly what the firm wants to achieve (BALDASSARRE; CAMPO, 2016). This is just what was found in the experiments held in this research.

Results showed that when exposed to discounts for a food basket, consumers did not compare options to identify packaging containing more water; also, consumer did not read nutritional facts about a juice or grape nectar; additionally, it did not matter to the consumer if a company adopts or not, greenwashing on its communications. Fundamental fact of interest for consumers was low price. When technical information on labels was highlighted, there was no change on consumption, on a perfect harmony between benefits and price. About seduction techniques used on packaging, consumer was not ingenious naive or seduced, because always looked up for lower prices, despite of losing 
quality or quantity. These considerations apply to a range of monthly average income per capita for low upper class of R\$2,480.00 or US\$ 715.00 .

It was clear, in this scenario, that the consumer is frequently seen as a victim of seduction. Looking up for low prices suggest consciousness on the availability of options. Previous research, like Luedicke, Thompson and Giesler (2010) and Clement, Kristensen and Grønhaug (2013), show ethical consumers, who are looking for the best practices tied to prices, checked with visual equipment for tracking, identifying good options on merchandise and its packaging. This means that the relation between promotional prices and the information showed on label, suggest that the nonseduced consumer will search for the best option.

The Meanings included on goods suggest that persuasion only works if the individual is willing to be persuaded. Seduction and persuasion need the presence of some aspects to create that situation. For Campbell (2005), this persuasion is about guiding consumers to make a decision that normally he would not make spontaneously, considering he would be in a context of expectations and increasing frustrations. There is a boundary for this persuasion to be perceived as to be vicious. It is like if someone else would agree to receive a persuasion. In this way, persuasion exists only when it is convenient for the individual.

This research studies these complexities through an experiment with persuasive packaging and aggressive actions of silent sales, contributing on the understanding of potentially aggressive strategies, and the consumer behavior facing strategies thought as persuasive.

There are also four theoretical contributions: firstly, the research offers an understanding about seduction and persuasion in marketing, as they require predisposition to have an effect. Secondly, this project shows that the costumer is not worried about the nutritional facts of a product, as he is about its price. On third place, highlighting information on label only in one product of a basket can create generalized consciousness for the whole goods. Finally, consumer does not perceive as harmful the effects of abuses like Trade Dress* or Greenwashing ${ }^{\dagger}$, if the products present a low price.

The question here is discussing persuasion subtlety present on some packaging of foods, when mixed up with others goods. After discussion, some stories will be considered to relate promotional pricing and information on labels and packaging on a options basket consumption.

\footnotetext{
* Trade Dress is a way in which a product is packed, labeled, disseminated or announced, including marketing strategies.

$\uparrow$ Greenwashing is a Green make up, when a firm pretends to be a concerned corporation, with sustainable practices on products and their packaging.
}

\section{Background literature}

On consumer and consumption context it is necessary to establish a value relation for individuals to create a persuasive effect. Is because of this, that "consumer victim of consumption" has a secondary role on seduction scenario, which would be another bias for consumption.

\subsection{Persuasion universe on consumption}

In semiotic and persuasion space, stimulation finds place when it fits meanings and interests, wishes and aspirations. A persuasion is born in a message organized to seem to satisfy needs of communicants. Is so every single message it's only a message when it's an answer to the questions, obligations and interests of the communicators (PERUZZOLO, 2011). In other words, an event with the objective of convincing with saying "that is important" must be discarded, because the meaning of importance will be completed when receptor processes the message.

A seduced consumer has a bias in which there is a victim in an "apocalyptic consumption society", a critic vision focused on needs and desires as the driving incentive for consumption. It is possible to foresee, in this context, what Douglas, Isherwood and Dentzien (2013) called as "veterinary preconception", when meanings on goods and services are postpone at a time of valorization and categorization of needs.

There is a limit for this seduction seen as bad. It is like if who is seduced is predisposed to openly receive seduction. This seduction is a guide that directs consumers to making a decision that normally he would not make spontaneously, just like if he would be in a context of revolutions of expectations and increasing frustrations. The metaphor of the hypodermic needle fits here, foreseeing that empty consumers will be injected by necessity of products and services (CAMPBELL, 2005).

It is possible to infer from some cultures that details of labels may be unnoticed or understood in some other ways. Cultural formation is dominant for perceptions on packages. Gomez and Torelli (2015) explain with a chart comparing the ways in which North American and French people make their choices and how they make the interpretations of favorable information on foods. Culture, here, is a delimiter between needs or wishes and their meanings. This interpretation goes through what Miller (2013) and Campbell (2005) proposed as the dialog between ipleasure buying and common and sacrificing buying? Without any doubt, pleasure buyers are those exposed to seduction.

The role played by advertisement is merely one part of all the influences acting on consumers. Market is not homogeneous, turning every individual into a different agent, because of the diversity on reception of messages, 
answering therefore, in an intentional and differentiated way. About this persuasive practice, it is supposed that a manipulating individual of its media practices must deeply know others motivations. Symbolic meanings are included on goods, not on consumers or on their needs (CAMPBELL, 2005). On specific cases of packaging, there is a situation of mass production. If the objective of a label is to persuade, it must be created to reach thousands of consumers interpreting the same message.

Recurrently, persuasion is related to a shopping mall and other consumption places. Certainly, this space has been target of critics related to overconsumption and to a futile adventure of purchasing. Other territories must be considered, like e-commerce. Sales are about gaining access, and not about products, creating a need of establishing new ways of socialization, communications, and the ignored development of practices relating subjectivity with a material culture. If these aspects were taken in consideration, there would be people involved in rationality processes and canceled subjectivities (BARBOSA; CAMPBELL, 2006). Taking the example of packaging seen as a silent seller, effectivity will occur when environment is warm and receptive.

Persuasion is a symbolic trick tending to convince others about changing their attitudes or behaviors through the transmission of a message in a free choice environment (PERLOFF, 2010). It is about an influence activity that turns out to be effective when attitudes and opinions are modified creating new emotions (PARSONS, 1963). There is a fundamental factor for persuasion turning effective, consisting in the identification of a circumstance that allows an answer. Persuading is both pleasing as convincing; so that men can govern more by caprice than by reason (PASCAL, 1985).

This persuasion may occur with the consumer not perceiving its processes, and being hiden even on inoffensive questions (WILLIAMS; FITZSIMONS; BLOCK, 2004), just like it happens on interpersonal communications as word of mouth (BERGER, 2014), and turns to be more effective if the argument is used with other technical knowledge (BHATTACHERJEE; SANFORD, 2006; SUSSMAN; SIEGAL, 2003). If the goal of the practice is to persuade through processes of motivation, memory, learning, perception, social interaction, personality development, cognitions and language, the first step would be to select contingencies of reinforcement, fundamental on each situation (SIDMAN, 1989). In the same way, Cialdini (2001) shows six main principles that guide persuasion: reciprocation; linking; commitment and consistency; social proof; authority and scarcity. These principles are more effective when suggesting automatic processing of information. Being indifferent about the result of a persuasive message, hurried, stressed out, distracted or tired are situations that drive a person to using automatic processing. Boush, Friestad and Wright (2009) talk about misleading advertising as the more explored automatic resource with the aim of breaking barriers of consumer resistance.

Persuasion is a trite and frequent act on daily consumption practices. Everyone, eventually, tries to persuade through encouragement, flattery, praise or reward, making it clear that failure on answering to expectations and exigencies will result on withdrawing of already given rewards. A subtle persuasive effect is exemplified on the study of Ketelaar et al. (2016). Authors tested the effect of physical proximity between two individuals, as a persuasion of consumption in a store. Results indicate that emotions triggered by proximity would influence purchasing satisfaction, aversive behavior, willing to buy and number of alternatives considered. Another example related to the subtleness of persuasion was made by Das (2016), who researches nonverbal communications on the effectivity of retailing sales. Sellers who received training of simple aspects as tone of voice and personal hygiene, were more effective than those without training. Making more effective sales practices may be extended to the consumer, with the intention of creating more consciousness on his practices (BUBLITZ et al., 2013).

Pratkanis (2011) organized about 100 influence tactics in four categories empirically tested: (1) Ambiance (environment is prepared for persuasion being more effective); (2) Social (tactics about social relations); (3) message effectivity (persuasive message manipulation for increasing the power of the persuasion); (4) emotions (calling to emotions, feelings and attitudes). In a research looking for measuring the success of influencing practices on consumption, Pandelaere et al. (2010) analyzed concordance on facts unrelated to purchasing routines in a store. Elements as "I think it is allowed that women pay less than men" were told with the objective of identifying if sales were more or less effective. Authors found that people turn to be willing to buy when there is concordance on discussion, despite of controversy. For Reich and Tormala (2013), when it is intended to change other people's minds, or to influence their decisions, it is required to send a consistent message or to repeat the principal opinion of who is willing to persuade.

Virtual world also is the result of empirical studies when persuasion is researched. This space is usually tied to consumers evaluations, expert evaluations, or special discount products are presented (KAPTEIN; ECKLES, 2012). Kukar-Kinney, Scheinbaum and Schaefers (2016) created a motivation theory of online buyer behaviour for promotions, focusing on compulsive buyers. This theory 
offers answers to attitudes like the effect of increasing time pressure (product only available for today). Strategies like this one, must be oriented to consumer reality, because even when misinterpreted it is going to cause other strategies related to stock and fabulous selling, as 'reduced stock' and "more than a million of copies sold" (KAPTEIN; ECKLES, 2012). It is noteworthy that due to offer excess and the variety of products, such practices are successful only when the consumer is predisposed. Devolution, for example, may be cause of dissatisfaction, turning into a loss for suppliers.

The scale proposed by Modic (2013) and Modic and Lea (2013) suggest a way to find persuasion practices and to avoid internet scam. The scale defines influence of authority, social influence, self-control and the need for consistency as its dimensions. Uncertainty factor is fundamental for persuasion process (KUPOR; TORMALA; NORTON, 2014). The Authors quote a case of a phrase like "She could turn into" that may be more persuasive than "she is". With regard to increase ads efficiency, warning text must not include technical descriptions, but clear ones about potential negative results (MODIC; ANDERSON, 2014). A direct warning has to be prioritized over an authority position. Specific warnings are more effective than abstract ones. Affective positioning on work brings better effects than tough ones. Social influence seems to be less efficient than a trend. Actually, using coercion (instead of persuasion) has to be minimized once it is known to be counterproductive.

In this scenario, seduction turns out to be a message that creates, reinforces or changes others answers (KLUCHAREV; SMIDTS; FERNANDEZ, 2008). Depending on how they are created, these messages may change the consumer's decision process, establishing not projected standards. This information tends to generate immediate and concrete promises for products and services. On the choosing process there are four stages, defined by Mowen and Minor (2003): problem recognition, research, alternatives analysis, and choosing and evaluation. Knowing this path, persuasion may take one of two routes: peripheral and central. The difference is on the consumer's level of involvement. On the central route, there is a wise consumer focused on the message. On the other hand, authors describe that on the peripheral route, the analysis of pros and cons is absent. Under low involvement circumstances, there may be changes on beliefs, but attitudes and feelings do not receive influence. Therefore, persuasion occurs in universes of beliefs or of arguments and context motivations. In other words, music or fragrances may cause persuasion, and this can be wicked for authors with a critical approach of consumption.

\subsection{Persuasion with Greenwashing and Trade Dress}

Modern tactics for labels and packaging must be seen as sophisticated persuasions. There are two common and pragmatic examples perceived as a trend among packaging designers: Greenwashing and Trade Dress.

Greenwashing works as a makeup to hide real intentions through dissemination of products seen as ecological. It is a correct, sustainable or eco-friendly environmental and ecological speech, regarding to link the promoter's image of that information to preservation causes, although they are generating impacts on the environment and, in worst cases harmful impacts on ecosystems. Greenwashing have to be analyzed as misleading advertising (MAHONEY et al., 2013). Some related examples are:

1. "Disguised cost": the communication calls the consumer attention on a process, but do not explain the development of the process. For example: recycled paper may consume more water and energy than non-recycled paper. Green paper becomes a new product after the process. It may wonder what the cost of such operation might be?

2. "Absence of evidence": product says it good for the environment, but it does not say how. It may be questioned how much an industrialized product can return organic essence to nature?

3. "Uncertainty": a product sold as sustainable, but there are no indications about if it is the product by itself or is it about its packaging. If the product is perceived as natural, it would also be expected for its packaging.

4. "Irrelevance": the product says it has an eco-friendly attribute, but that isn't mandatory or may be mandatory. What is required by legislation turned to be a competitive resource?

5. "Less bad": manufacturer must inform healthy issues product may cause, because of its composition. There is a relevant information omission.

6. "Lie": manufacturer presents an inexistent label. Disclosed information does not reflect reality.

7. "Misleading label worship": manufacturer discloses a sustainable product certified by firm itself. The Certification is not provided by an international organism.

Green speech can be reduced to a communication guided by a green and politically correct trend. In this research a greenwashing product is analyzed: Steel wool Bombril Eco. The adopted certification was created by manufacturer, not by a certifier organization. 
Trade Dress is a legal protection practice for products and there packaging. It is a protection form for intellectual property, attaining from brand imitation to the subtle copy that can confuse the consumer. It is about colors, shapes, packaging, labels, among others (LE ROUX; BOBRIE; THÉBAULT, 2016). The product analyzed is called Mr. Muscle, offered with label similar to the top seller: CIF. Quantity, shapes and design are similar, just like their prices.

\section{Methodology}

A two experiment research was held with a "before" and "after" structure for participants. Experiment 1 including questions about which of the two products you would buy for its "normal" price, and then, which ones would buy for "promotional" price. Experiment 2 shows improvement of information on products labels, highlighting information about quantity and nutritional and quality facts. Alternative hypotheses to center research question are described (SIMMONDS; SPENCE, 2016; SILVA et al., 2017; MARTINHO et al., 2015): SPENCE

H1: Price reduction inhibits the attention on information included on persuasive packaging.

$\mathrm{H} 2$ : Increasing information included in labels reduces consumption of persuasive packaging.

\subsection{Participants}

Criteria for selecting participants were: frequent consumers of food and cleaning product retail (Regular and monthly purchases for the home), more than 18 years old and non-university students. With these criteria it was intended not to include people with knowledge on persuasion strategies in marketing campaigns. Then, 60 randomly selected participants were interviewed. Predominantly, the participants were male (55\%); Classified as low upper class (R $\$ 2,480.00$ or US $\$ 715.00$ percapta monthly income).

\subsection{Experimental design}

The approach to the consumers was random; they were asked if they were responsible for home purchases. A Federal University of Goiás student collected data. The Consumers were taken to a shelf in the supermarket, where products and prices were shown. A sheet was used to collect data, including demographic information at the end of interview.

In the sequence, analyzed products are described.

Mineral water in presentations of $350 \mathrm{ml}, 330 \mathrm{ml}$ and $310 \mathrm{ml}$. These three options were included in the study because of packaging physical similarity. If the consumer would not read the label, he will hardly identify they have different quantities. The Presentation of these three options suggests the consumption of traditional size of $500 \mathrm{ml}$.

Repellent Mats. Mats against mosquitoes have different acting times. Packaging suggest more and longer sleep nights; however, lower prices represent shorter lasting, and even displaying information about lasting " $\mathrm{x}$ " sleep nights, do not show any definition of what it would be a sleep night.

Yogurt and Dairy beverages, Dairy beverages are produced from whey, a liquid product resulting of cheese production. On the other hand, yogurt is bacteria fermented milk, so these are two different products, but with barely perceptive differences on packaging, which also used similar typographies and color use strategies to call consumers attention.

Sweetener and Sweetener Plus. Sweetener offers a drop for every sugar tablespoon, while another product of the same company, called plus, reaching the same objective with the same drop quantity, but $30 \%$ more expensive. Composition is the same.

Juice and Nectar, Grape Juice analyzed here is totally made from grapes juice, and Nectar has just $40 \%$ of juice. Both of them are very similar, confusing consumer on his choices. The cheaper product is more consumed, even when it is a sub product of grapes juice.

Cream cleaner. This a typical imitation of follower design: similar packaging to competitors. Analysis made for packaging shows confusion in choices, at first glance, products may mislead consumers.

Sponge/Steel Wool. Analyzed products emphasized on an attribute that makes them more expensive: ecological or sustainable. The idea was to verify how much this dubious appeal would be seen as interesting and differential for consumption. Product included in experiment received a quality certification granted by manufacturer and owner of the brand. Furthermore, the product informs to be good for the environment, but does not explain how or why. In 2004, a group of consumers, together with a national council of advertising regulation, presented an appeal against this company, asking them to stop using the slogan " $100 \%$ ecological", because of the difficult on testing its validity. Although the concept "Bombril Eco" is still being used (CONSELHO..., 2017). Price tags were design to create similarity to those frequently used on retail, taking advantage of the consumption environment. The Consumers seldom visits the supermarket just to buy one product of plenty of options.

† Conselho Nacional de Autorregulamentação Publicitária (Conar) 


\subsection{Practical scheme}

\subsubsection{Control of strange variables (VEs)}

We estimated two possible foreign variables in the experiment: consumption and brand environment. We avoided applying the research to the point of purchase and using different brands for the evaluated products.

\section{Discussion}

\subsection{Experiment 1}

\subsubsection{Design}

In February 2016, 60 people were asked to be involved in the research, showing seven different products displayed on a table, everything with the respect prices, similar to the prices offered in retailing, simulating a supermarket shelf.

\subsubsection{Procedure}

On a control sheet, every answer to "Which of this products would you buy for this price?" was registered.

In a second moment, some products will have a manipulated labels: Mineral water Indaiá $310 \mathrm{ml}$; Dairy Beverage Paulista (Fruits Pulp); Sweetener Assugrin Plus; 100\% Grapes Nectar, Cream Cleaner Mr. Muscle and Steel Wool Bombril Eco. These products were chosen because of the effectivity of their labeling tactic. Again, participants were asked which products they would buy. Data collected, including age and family income, were tabulated in a spreadsheet.

\subsubsection{Operational variables}

OV1: Price (20\% reduction on products' price)

\subsubsection{Theoretical variables}

TV1: Persuasion (consumption realization)

\subsubsection{Analysis}

In experiment 1 the consumer must indicate the products he would buy. Prices were normal, the same offered in retail. Then, products seen as persuasive ones were tagged with promotional prices. Results showed clear changes in three products consumption. Products with promotional price were: Mineral water Indaiá 310ml; Dairy Beverage Paulista (Fruits Pulp); Sweetener Assugrin Plus; 100\% Grapes Nectar, Cream Cleaner Mr. Muscle and Steel Wool Bombril Eco.

Reported results in Table 1 show that only the Cream Cleaner (0.0082) and the Dairy Beverage (0.0047) significantly influenced research questions. Using $p$-value criteria, it was observed a moderated influence of the Sweetener.
Due to the small sample size and paired data, median was the appropriate measure of central tendency, using Wilcoxon as the statistical test for the analysis. Through results in Table 1, can be observed that median was different before and after in the "sweetener", "cream cleaner" and "dairy beverage" cases, with an unilateral probability of 0.05 . Price reduction, in fact, inhibits the attention on information included on persuasive packaging of grapes juice, clean cleaner and yogurt, with moderated and significant influences.

\subsection{Experiment 2}

\subsubsection{Design}

Experiment 2 followed the same procedures of experiment 1 , but asking consumers about how would their goods basket be, considering offered prices. New labels were created to enhance information level of packaging about composition and quantity. Characteristics about being persuasive or not were highlighted: bigger font size about water quantity in mineral water bottles; juice percentage in each product ( $40 \%$ for nectar and $100 \%$ for juice); and sweetener drops per product (normal and plus). Steel wool information was the only product not manipulated.

\subsubsection{Procedure}

On a control sheet, every answer to "Which of this products would you buy for this price?" was registered.

In a second moment, the handled labels were as follows: Mineral water Indaiá 310ml; Dairy Beverage Paulista (Fruits Pulp); Sweetener Assugrin Plus; 100\% Grapes Nectar, Cream Cleaner Mr. Muscle and Steel Wool Bombril Eco. These products were chosen because of the aggressive labeling tactic. Again, it was asked to participants which products would they buy. Data collected, including age and family income, were tabulated in a spreadsheet.

\subsubsection{Operational variables}

VO2: Label (change in labeling information)

\subsubsection{Theoretical variables}

TV1: Persuasion (consumption realization)

Table 1. Influence on research question.

\begin{tabular}{|c|c|c|}
\hline Produts & p value & $\begin{array}{c}\text { Influence on research } \\
\text { question }\end{array}$ \\
\hline Mineral water & 0.5637 & Little or none \\
\hline Repellent Mats & 0.6547 & Little or none \\
\hline Sweetener & 0.0455 & Moderated \\
\hline Grapes Juice and Nectar & 0.3173 & Little or none \\
\hline Cream cleaner & 0.0082 & Very strong \\
\hline Yogurt and Dairy beverage & 0.0047 & Very strong \\
\hline Steel Wool & 0.5640 & Little or none \\
\hline
\end{tabular}




\subsubsection{Analysis}

Due to the small sample size and paired data, median was the appropriate measure of central tendency, using Wilcoxon as the statistical test for the analysis. Through results in Table 2, can be observed that median was different before and after in "mineral water" and "juice and nectar" cases, with an unilateral probability of 0.05 . Increasing information included in packaging reduces consumption of mineral water and grape nectar, with suggestive and moderate influences on research question.

According to Figure 1, the choices of some products were significantly modified. Adding extra information in labels caused a different behaviour in choosing these products: mineral water, repellent mats and grapes juice/nectar.

Other product choices were not significantly influenced. This means that adding extra information in labels was not enough for a change on consumer behavior for these products: sweetener normal/plus, cream cleaner, yogurt/dairy beverage, steel wool.

Yet, based on results on Figure 1, it can be observed that choices changed significantly in three categories of products: mineral water, repellent mats and grapes juice/nectar. Therefore, in experiment 2, $\mathrm{H} 1$ and $\mathrm{H} 2$ were rejected.

Table 2. Influence on research question.

\begin{tabular}{|c|c|c|}
\hline Products & p value & $\begin{array}{c}\text { Influence on research } \\
\text { question }\end{array}$ \\
\hline Mineral water & 0.0955 & Suggestive \\
\hline Repellent Mats & 0.1745 & Little or none \\
\hline Sweetener & 0.1572 & Little or none \\
\hline Grapes Juice and Nectar & 0.0455 & Moderate \\
\hline Cream cleaner & 0.1572 & Little or none \\
\hline Yogurt and Dairy beverage & 0.1797 & Little or none \\
\hline Steel Wool & 0.5637 & Little or none \\
\hline
\end{tabular}

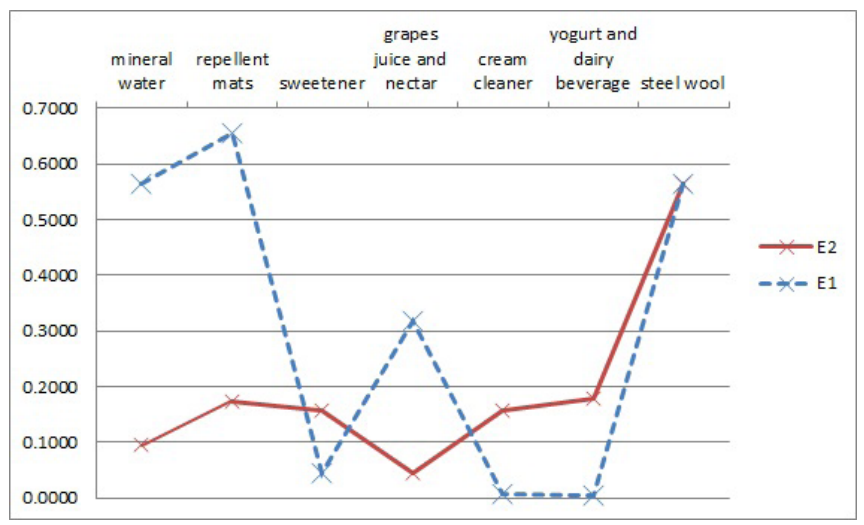

Figure 1. Practical scheme.
Choices of steel wool Bombril Eco did not change, noticing that any information was added to its label, so that it remained just like presented in experiment 1.

\section{General discussion}

\subsection{Interpretation of findings}

Experiment 1 supported $\mathrm{H} 1$ for three products: Sweetener Normal/Plus, Cream Cleaner and Yogurt/Dairy Beverage. When manipulating labels adding information about quantity and composition, answering behavior was homogeneous. In a pragmatic form, responding results were balanced, as if the consumer was prepared about tactics and differences of persuasion. In other words, consumer is now more conscious on consumption.

Figures 2 and 3 refer to the procedure of manipulating the price tags of the experiment. Table 3 shows the general scheme for experiment 1 and 2 .

Persuasion happens on a conscious consumption level. Participants changed their preferences to promotional products, ignoring elements like information levels on labels, even when it meant a diminution of quantity in packaging in mineral water bottles. It must be paid attention to the fact that none of the interview consumers tried to calculate which option could represent cost-benefit relationship, a fact that was expected to happen on mineral water bottles, since each one had a different quantity $(310,330$ and $350 \mathrm{ml})$.

In experiment 2 it was observed homogeneity in choices. Increasing information level created a scenario in which consumer was just an observer of foreseen differences in every option, supplying balanced results. The consumption

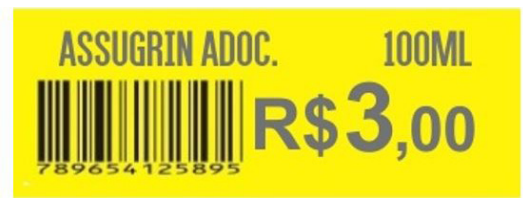

Figure 2. Discount price.

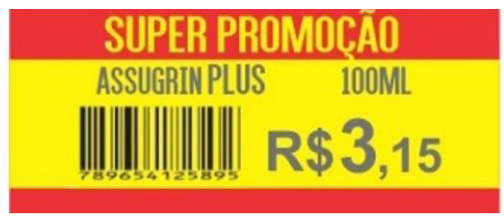

Figure 3. Price without discount.

Table 3. Practical scheme.

\begin{tabular}{|l|c|c|c|c|}
\cline { 2 - 5 } \multicolumn{1}{c|}{} & \multicolumn{2}{c|}{ Experiment 1 } & \multicolumn{2}{c|}{ Experiment 2 } \\
\cline { 2 - 5 } \multicolumn{1}{c|}{} & Before & After & Before & After \\
\hline Price & Normal & Promotional & Normal & Normal \\
\hline Label & Normal & Normal & Normal & Altered \\
\hline
\end{tabular}


basket was seen as set of items, not as individual ones, as observed in experiment 1 , suggesting an evolved consumer that perceives purchasing as a consumption unit.

\subsection{Theoretical and managerial contributions}

Economic theories foresee consumer as a homo economicus, while behavioral economic theory suggest an interference of subjectivity in logical choices. In this research, a warning with isolated products was given to consumer, resulting in a generalized warning for the whole basket. Consumer reacted paying more attention on every subtle detail in packaging of the other products.

Theoretical contribution: the consumer should be seen as an individual of groupings of products and not of isolated items. Excession is made for the case of Greenwhasing which has presented itself as an effective practice of market seduction. Consumer units or Diderot units have been investigated as a consumer effect for a specific consumer choice over subsequent goods (BELK, 1995; FOURNIER, 1998; MCCRAKEN, 1990).

Practical contribution: from applied studies aimed at the search for consumer well-being and quality of life (BELL; EMORY, 1971; SHETH; PARVATLYAR, 1995), we seek in this study to highlight healthy marketing practices that have less adverse effects on consumption and after sales of goods. Studies on Transformative Consumer Research (DAVIS; PECHMANN, 2013; MICK et al., 2012).

As a managerial contribution, the study presents evidence of an instructed and conscious consumer. Furthermore, the research shows than a product known to be manufactured or disclosed with abusing practices, may trigger an analyzing effect for other unethical practices used in persuasion, just like Traderess and Greenwashing.

\section{References}

BALDASSARRE, F.; CAMPO, R. Sustainability as a marketing tool: to be or to appear to be? Business Horizons, v. 59, n. 4, p. 421-429, 2016. http://dx.doi.org/10.1016/j. bushor.2016.03.005.

BARBOSA, L.; CAMPBELL, C. Cultura, consumo e identidade. Rio de Janeiro: FGV, 2006.

BELK, R. Possessions and the extended self. The Journal of Consumer Research, v. 15, p. 139-168, 1995.

BELL, M.; EMORY, W. The faltering marketing concept. Journal of Marketing, v. 35, n. 4, p. 37-42, 1971. http:// dx.doi.org/10.2307/1250455.

BERGER, J. Word of mouth and interpersonal communication: a review and directions for future research. Journal of Consumer Psychology, v. 24, n. 4, p. 586-607, 2014. http:// dx.doi.org/10.1016/j.jcps.2014.05.002.
BHATTACHERJEE, A.; SANFORD, C. Influence processes for information tech-nology acceptance: an elaboration likelihood model. Management Information Systems Quarterly, v. 30, n. 4, p. 805-825, 2006.

BOUSH, D. M.; FRIESTAD, M.; WRIGHT, P. (2009). Deception in the marketplace: the psychology of deceptive persuasion and consumer self-protection. New York: Routledge.

BUBLITZ, F. et al. Pervasive advertising: an approach for consumers and advertisers. In: IEEE INTERNATIONAL CONFERENCE ON CONSUMER ELECTRONICS, 3., 2013, Berlin. Proceedings... USA: IEEE, 2013. p. 290-294.

CAMPBELL, C. The romantic ethic and the spirit of modern consumerism. Oxford: WritersPrintShop, 2005.

CIALDINI, R. B. Influence: science and practice. New York: Haper Colins, 2001.

CLEMENT, J.; KRISTENSEN, T.; GRØNHAUG, K. Understanding consumers' in-store visual perception: the influence of package design features on visual attention. Journal of Retailing and Consumer Services, v. 20, n. 2, p. 234-239, 2013. http://dx.doi.org/10.1016/j. jretconser.2013.01.003.

C O N S E L H O B R A S I L E I R O D E AUTORREGULAMENTAÇÃO PUBLICITÁRIA. Boletim do CONAR, v. 212, 2017. Disponível em: <www. conar.org.br.. Acesso em:

DAS, G. Influence of salespersons' nonverbal communication cues on consumer shopping behaviour. Journal of Retailing and Consumer Services, v. 31, p. 199-206, 2016. http:// dx.doi.org/10.1016/j.jretconser.2016.02.009.

DAVIS, B.; PECHMANN, C. Introduction to the Special Issue on transformative consumer research: developing theory to mobilize efforts that improve consumer and societal well-being. Journal of Business Research, v. 66, n. 8, p. 1168-1170, 2013. http://dx.doi.org/10.1016/j. jbusres.2012.08.008.

DICHTER, E. The package and the label. London: Packaging Carton Research Council, 1957.

DOUGLAS, M.; ISHERWOOD, B.; DENTZIEN, P. O mundo dos bens: para uma antropologia do consumo. Rio de Janeiro: UFRJ, 2013.

FOURNIER, S. Consumers and their brands: developing relationship theory in consumer research. The Journal of Consumer Research, v. 24, n. 4, p. 343-373, 1998. http:// dx.doi.org/10.1086/209515.

GOMEZ, P.; TORELLI, C. J. It's not just numbers: cultural identities influence how nutrition information influences the valuation of foods. Journal of Consumer Psychology, v. 25 , n. 3, p. 404-415, 2015. http://dx.doi.org/10.1016/j. jcps.2015.01.005. 
HANSEN, U. Verpackung und konsumentenverhalten (packaging and consumer attitudes). Journal of Marketing Management, v. 8, n. 1, p. 5-12, 1986.

KAPTEIN, M.; ECKLES, D. Heterogeneity in the effects of online persuasion. Journal of Interactive Marketing, v. 26, n. 3, p. 176-188, 2012. http://dx.doi.org/10.1016/j. intmar.2012.02.002.

KETELAAR, P. E. et al. The success of viral ads: social and attitudinal predictors of consumer pass-on behavior on social network sites. Journal of Business Research, v. 69, n. 7, p. 2603-2613, 2016. http://dx.doi.org/10.1016/j. jbusres.2015.10.151.

KLUCHAREV, V.; SMIDTS, A.; FERNÁNDEZ, G. Brain mechanisms of persuasion: how 'expert power'modulates memory and attitudes. Social Cognitive and Affective Neuroscience, v. 3, n. 4, p. 353-366, 2008. PMid:19015077. http://dx.doi.org/10.1093/scan/nsn022.

KUKAR-KINNEY, M.; SCHEINBAUM, A. C.; SCHAEFERS, T. Compulsive buying in online daily deal settings: an investigation of motivations and contextual elements. Journal of Business Research, v. 69, n. 2, p. 691-699, 2016. http://dx.doi.org/10.1016/j.jbusres.2015.08.021.

KUPOR, D. M.; TORMALA, Z. L.; NORTON, M. I. The allure of unknown outcomes: exploring the role of uncertainty in the preference for potential. Journal of Experimental Social Psychology, v. 55, p. 210-216, 2014. http://dx.doi. org/10.1016/j.jesp.2014.07.004.

LE ROUX, A.; BOBRIE, F.; THÉBAULT, M. A typology of brand counterfeiting and imitation based on a semiotic approach. Journal of Business Research, v. 69, n. 1, p. 349356, 2016. http://dx.doi.org/10.1016/j.jbusres.2015.08.007.

LEWIS, M. Understanding brands. London: Kogan Page, 1991.

LUEDICKE, C. J.; THOMPSON, M.; GIESLER, M. Consumer identity work as moral protagonism: How myth and ideology animate a brand-mediated moral conflict. The Journal of Consumer Research, v. 36, n. 6, p. 1016-1032, 2010. http://dx.doi.org/10.1086/644761.

MAHONEY, L. S. et al. A research note on standalone corporate social responsibility reports: signaling or greenwashing? Critical Perspectives on Accounting, v. 24, n. 4, p. 350359, 2013. http://dx.doi.org/10.1016/j.cpa.2012.09.008.

MARTINHO, G. et al. Factors affecting consumers' choices concerning sustainable packaging during product purchase and recycling. Resources, Conservation and Recycling, v. 103, p. 58-68, 2015. http://dx.doi.org/10.1016/j. resconrec.2015.07.012.

MCCRAKEN, G. D. Culture and consumption: new approaches to the symbolic character of consumer goods and activities. Indiana: Indiana University Press, 1990.
MICK, D. G. et al. Transformative consumer research for personal and collective well-being. New York: Routledge, 2012.

MILLER, D. A theory of shopping. John Wiley \& Sons, 2013.

MODIC, D. Willing to be scammed: how self-control impacts Internet scam. Exeter: University of Exeter, 2013.

MODIC, D.; ANDERSON, R. Reading this may harm your computer: the psychology of malware warnings. Computers in Human Behavior, v. 41, p. 71-79, 2014. http://dx.doi. org/10.1016/j.chb.2014.09.014.

MODIC, D.; LEA, S. E. G. (2013). Scam Compliance and the Psychology of Persuasion. Social Sciences Research Network. In press.

MOWEN, J. C.; MINOR, M. S. Consumer behavior: a framework. Upper Saddle River: Prentice-Hall, 2003.

PARSONS, T. On the concept of influence. Public Opinion Quarterly, v. 27, n. 1, p. 37-62, 1963. http://dx.doi. org/10.1086/267148.

PASCAL, B. De l'esprit géométrique. In: CLAIR, A. (Ed.). Ecrits sur la Grace et autres textes. Paris: Flammarion, 1985.

PERLOFF, R. M. The dynamics of persuasion: communication and attitudes in the twenty-first century. Routledge, 2010.

PERUZZOLO, A. C. Persuasão, erotismo e sedução. Comunicação Mídia e Consumo, v. 7, n. 20, p. 317-334, 2011.

PILDITCH, J. Packaging for profits: a perfectly sound product idea can be sidelined by attractive but impractical packaging. American Demographics, v. 33, 1961.

PRATKANIS, A. R. (Ed.). The science of social influence: advances and future progress. Psychology Press, 2011.

REICH, T.; TORMALA, Z. L. When contradictions foster persuasion: an attributional perspective. Journal of Experimental Social Psychology, v. 49, n. 3, p. 426-439, 2013. http://dx.doi.org/10.1016/j.jesp.2013.01.004.

SHETH, J. N.; PARVATLYAR, A. Relationship marketing in consumer markets: antecedents and consequences. Journal of the Academy of Marketing Science, v. 23, n. 4, p. 255 271, 1995. http://dx.doi.org/10.1177/009207039502300405.

SIDMAN, M. Coercion and its fallout. Boston, 1989.

SILVA, A. R. et al. Impact of sustainability labeling in the perception of sensory quality and purchase intention of chocolate consumers. Journal of Cleaner Production, v. 141, p. 11-21, 2017. http://dx.doi.org/10.1016/j. jclepro.2016.09.024.

SIMMONDS, G.; SPENCE, C. Thinking inside the box: How seeing products on, or through, the packaging influences consumer perceptions and purchase behaviour. Food Quality and Preference, 2016. 
SUSSMAN, S. W.; SIEGAL, W. S. Informational influence in organizations: an integrated approach to knowledge adoption. Information Systems Research, v. 14, n. 1, p. 47-65, 2003. http://dx.doi.org/10.1287/isre.14.1.47.14767.
WILLIAMS, P.; FITZSIMONS, G. J.; BLOCK, L. G. When consumers don't recognize "benign" intentions questions as persuasion attempts. The Journal of Consumer Research, v. 21, n. 3, p. 540-550, 2004. http://dx.doi.org/10.1086/425088. 